\title{
Tożsamość i niepewność. Życie osób po przeszczepach płuc
}

Łucja Lange

TEKSTY DRUGIE 2021, NR 1, S. 155-171

DOI: 10.18318/td.2021.1.9 | ORCID: 0000-0002-2676-1022

\section{Wstęp}

Przeszczep płuc jako temat jest stosunkowo rzadko podejmowany przez badaczki i badaczy, jeśli weźmiemy pod uwagę publikacje z zakresu etyki, bioetyki, filozofii czy socjologii. Częściej pojawiają się opracowania dotyczące życia po przeszczepie innych organów, np. nerki, wątroby czy kończyn'. W zależności od tego, jaka była pierwotna przyczyna znalezienia się na liście biorców (Krajowa Lista Oczekujących na Przeszczepienie, KLO), różnie wygląda kwestia kształtowania się tożsamości pacjentek i pacjentów po transplantacji, przy czym przez

1 Zob. I. Cymerman Doświadczenie jakości życia po przeszczepie - perspektywa fenomenologiczno-hermeneutyczna, Wydawnictwo Uniwersytetu Warmińsko-Olsztyńskiego, Olsztyn 2007 (przeszczep wątroby, nerki); K. Kowal Między altruizmem a egoizmem. Społeczno-kulturowe uwarunkowania przeszczepów rodzinnych, Wydawnictwo Adam Marszałek, Toruń 2011 (przeszczepy nerek); K. Kowal Doświadczenie własnej cielesności przez biorców kończyny - socjologiczne studium zrekonstruowanego ciała, „Przegląd Socjologii Jakościowej” 2012 t. VIII nr 2, s. 152-199.
Łucja Lange - pracownica Wydziału Ekonomiczno-Socjologicznego Uniwersytetu Łódzkiego, doktorantka Instytutu Socjologii U $Ł$ oraz IBL PAN (Humanistyka Cyfrowa), członkini EACAS, IA for Vegan Sociologists, sekcji Relacji Międzygatunkowych PTS oraz kolektywów: Instytut Dobrej Śmierci i Radical Death Studies. Poza zagadnieniami animal studies zajmuje się badaniami kancerografii w sieci oraz badaniami doświadczenia żałoby po dziecku. 
tożsamość rozumiem samookreślanie siebie w czasie i przestrzeni w odniesieniu do ludzi i zdarzeń, rodzaj odnajdywania się uzależniony od zmieniających się ról społecznych, autoidentyfikację². Niewielka liczba publikacji podejmujących temat przeszczepu płuc jest między innymi wynikiem tego, że przeszczepów takich wykonuje się stosunkowo mało w porównaniu z pozostałymi ${ }^{3}$. Dodatkowo są one uważane za najtrudniejsze i obarczone najwyższym współczynnikiem odrzutów, a więc i niższą przeżywalnością̧. Tym samym sytuacja osób z przeszczepionymi płucami jest inna niż osób chociażby po przeszczepie trzustki czy nerki. Podstawą dla niniejszego artykułu są dwa wywiady, które pochodzą z badań własnych. Pierwszy należy do zbioru doświadczeń żałoby po dziecku ${ }^{5}$ - rozmówczyni jest po trzydziestce, płuca przeszczepiono jej jako jednej z pierwszych osób w Polsce i obecnie jest najdłużej żyjącą osobą po przeszczepie płuc. Drugi wywiad pochodzi ze zbioru doświadczeń przeszczepu organów ${ }^{6}$. Rozmówca jest powyżej czterdziestki, pierwszą operację przeszczepu przeszedł jako dorosły człowiek, następnie, po odrzucie, przeszczepiono mu płuca po raz drugi. Wywiad narracyjny jako stymulowana opowieść o przeżyciach i doświadczeniach jest wyjątkowym sposobem pozyskiwania danych jakościowych. Pozwala na poznanie zrekonstruowanego przebiegu życia oraz punktu widzenia jednostki, która uczestniczyła w danych uwarunkowaniach społecznych i kulturowych? Wywiad narracyjny ma również potencjał dla medycyny narracyjnej, której celem jest inicjowanie i interpretowanie opowieści o doświadczeniach

2 Por. Z. Bauman Ponowoczesne wzory osobowe, "Studia Socjologiczne" $1993 \mathrm{nr}$ 2, s. 7-31; Z. Bokszański Tożsamość jednostki, „Kultura i Społeczeństwo” 1988 t. 32 nr 2, s. 3-17; Wokół problemów tożsamości, red. A. Jawłowska, Wydawnictwo LTW, Warszawa 2001.

3 T. Grodzki Dylematy transplantologii płuc w Polsce, „Pneumonologia i Alergologia Polska” 2007 t. 75 , nr 3, s. 251-255.

4 S. Gruber, T. Eiwegger et al. Lung transplantation in children and young adults: $a$ 20-year single-centre experience, "European Respiratory Journal” 2012 vol. 40, s. 462.

5 Rozmowa przeprowadzona została w roku 2016 - autoryzowana i zakodowana jako Ko1_ DN_20160520 w serii wywiadów z lat 2016-2019 (kod zmieniono na K01_MUKO_20160520 po włączaniu do serii dotyczącej doświadczenia przeszczepu). Po cytowanych fragmentach wywiadu podawane są wiersze, w których znajduje się dana wypowiedź.

6 Rozmowa przeprowadzona została w roku 2019 - zakodowana jako Mo1_MUKO_20190613 (badania w toku). Wywiad nie był autoryzowany, ponieważ rozmówca zmarł. Po cytowanych fragmentach podawane są wiersze, w których znajduje się dana wypowiedź.

7 Por. F. Schütze Biographieforschung und narratives Interview, „Neue Praxis. Kritische Zeitschrift für Sozialarbeit und Sozialpädagogik" $1983 \mathrm{nr}$ 13, s. 283-293. 
pacjentów oraz innych aktorów środowiska służby medycznej, a także reagowanie na nie ${ }^{8}$.

We wspomnianych wywiadach pierwszym ważnym momentem, na który zwracają uwagę opowiadający, jest pogarszający się stan zdrowia i diagnoza. Z jednej strony zmniejszająca się pojemność płuc zbliża pacjentów do śmierci, z drugiej - daje nadzieję na upragniony przeszczep i „nowe życie”. Na plan pierwszy wysuwają się marzenia o końcu cierpienia i szansa na coś, co jest postrzegane jako cud. Jest to okres, kiedy tożsamość badanych nie jest jeszcze naznaczona nieuleczalną chorobą. Diagnoza kończy okres niepewności i rozpoczyna etap świadomego postępowania z chorobą - wdrażania odpowiednich procedur, leków oraz zmiany codziennej rutyny.

Kolejnym istotnym wydarzeniem jest przeszczep i dochodzenie po nim do stanu, który można nazwać zdrowiem. Nie jest on jednak zdrowiem w powszechnym rozumieniu, ponieważ wiąże się z nieustannym uważaniem na siebie, przestrzeganiem zaleceń lekarskich, zażywaniem silnych leków, niekończącymi się kontrolami, powtarzającymi się infekcjami, a często widmem kolejnego przeszczepu lub śmierci. Negocjowanie statusu pomiędzy zdrowiem a chorobą jest więc stałym punktem w zebranych narracjach. Zmienia się percepcja własnego ciała oraz zdrowia. Również życiowe cele często ulegają przeobrażeniu. Świadomość, że przeszczep jedynie przedłuża życie, ale nie ratuje go w pełni, bo jest chwilowym „uporaniem się" z problemem, sprawia, że osoby po transplantacjach tego organu czasami kwestionują swoją decyzję o dążeniu do przeszczepu.

Zebrane narracje pokazują walkę o zdrowie i „normalne”, dostępne wszystkim życie. Są próbą zarazem oswojenia i ukrycia choroby. Pozwalają zauważyć jednocześnie wyjątkowość każdego przypadku i wspólnotę w poczuciu stygmatyzacji nieuleczalną chorobą.

\section{Diagnoza - mukowiscydoza}

Mukowiscydoza (zwłóknienie torbielowate, cystic fibrosis, CF) to choroba uwarunkowana genetycznie. Jej przebieg jest różny i nie zawsze pozwala na szybkie ustalenie, co powoduje pogarszanie się stanu zdrowia, ciągłe infekcje

8 R. Charon Narrative medicine. A model for empathy, reflection, profession, and trust, "Journal of American Medical Association" 2001 vol. 286 no. 15, s. 1897-1902. 
i uciążliwy kaszel. Uważa się, że to choroba „ogólnoustrojowa o różnorodnej ekspresji klinicznej"'.

W klasycznej (pełnoobjawowej) postaci występują zapalenia oskrzeli i płuc, niewydolność zewnątrzwydzielniczą trzustki, niepłodność mężczyzn oraz podwyższone stężenie $\mathrm{Cl}$ w pocie. Większość chorych wykazuje zaburzenia wielonarządowe, ale u części z nich choroba przebiega z prawidłową wydolnością trzustki. O jakości i długości życia zwykle decydują zmiany w układzie oddechowym. ${ }^{10}$

W latach 8o. i 9o. XX wieku diagnozowanie mukowiscydozy było procesem długotrwałym. Szczególnie kiedy pacjent nie wykazywał specyficznych dla choroby oznak, a obserwowany był jedynie przewlekły kaszel. Jakość życia osób chorych na mukowiscydozę jest różna, borykają się z nawracającymi schorzeniami - od sezonowych zachorowań po chroniczne zapalenia płuc i oskrzeli zakończone hospitalizacją i dożylną antybiotykoterapią. W biuletynie „Mukowiscydoza” prezentowane są różne sposoby radzenia sobie z uciążliwością życia z mukowiscydozą - jeśli już ktoś wie, że na nią choruje. „Chyba miałam sześć lat mniej więcej, jak zaczęłam kaszleć. Zawsze rano kasłałam. I moją mamę to zaniepokoiło i zaczęła mnie brać do kolejnych lekarzy" (35-37). Lekarz internista bagatelizował sprawę, uznając kaszel za normalny objaw, który z czasem sam przejdzie. W wieku ośmiu lat doszło do zachłyśnięcia wodą na basenie podczas obowiązkowych zajęć pływania. „Później zaczęłam kasłać bardziej. I w końcu wylądowałam [...] w szpitalu specjalistycznym” (51-55). W roku 1993 dziecko skierowano do specjalistycznego ośrodka chorób płuc, w którym liczono, że wreszcie zostanie postawiona diagnoza. Wstępnie badania prowadzono w kierunku zwłóknienia płuc. „Zaczęli mnie badać, robić te wszystkie prześwietlenia, robić różne badania krwi oczywiście, testy wydolnościowe [...]. I to wszystko wychodziło źle. Natomiast ja... wyglądałam na [...] zdrowe dziecko" (87-92). Testy nie kończyły się. Część z nich była stresująca i wryła się w pamięć, jako doświadczenie traumatyczne. Po dwóch miesiącach wysuwania alternatywnych pomysłów wykonano test, który potwierdził mukowiscydozę. Także mój drugi rozmówca wspominał, że diagnozowanie trwało latami. Jego diagnoza zbiegła się

\footnotetext{
9 J. Walkowiak, A. Pogorzelski i in. Zasady rozpoznawania i leczenia mukowiscydozy. Zalecenia Polskiego Towarzystwa Mukowiscydozy 2009, "Standardy Medyczne/ Pediatria” 2009 t. 6, s. 352. 
w czasie z narodzinami brata, który również był chory, przy czym chorobę przechodził ciężej i zmarł w wieku 16 lat.

Ponieważ w obu przypadkach diagnoza związana z chorobą przypadła na okres dzieciństwa i badani nie mieli dużych możliwości porównania siebie z innymi, uznali, że ich życie po diagnozie bardzo się zmieniło, ale te zmiany dość szybko stały się nową normą. Nie dostrzegali więc różnicy i swój stan (o którym niewiele wiedzieli) odbierali jako normalny. Jako dzieci nie byli informowani o specyfice swojej choroby. Traumatyczność diagnozy, o której wspominają autorki książki Tajemniczy świat muko" ${ }^{11}$ dotyczyła więc prawdopodobnie tylko rodziców, którzy nie chcieli obarczać tym ciężarem także potomstwa.

\section{Choroba wieku dziecięcego - negocjowanie pozycji „innego" i świadomość śmierci}

Poczucie bycia innym negatywnie wpływa na samoocenę, jest Goffmanowskim piętnem per se - obciąża i sprawia, że „inny” stara się dostosować do otoczenia, negocjuje swoją pozycję, by nie powodować negatywnych reakcji, i jednocześnie próbuje wtopić się w tłum ${ }^{12}$. To trudne, kiedy na każdym kroku „inność" wysuwa się na plan pierwszy.

„Lekarz, który się wtedy mną opiekował, powiedział im [rodzicom] wprost, że nie ma żadnej szansy, żebym ja dożyła do osiemnastu lat. Bo to jest choroba wieku dziecięcego [...] dzieci umierają po prostu" (132-135). Rodzice podjęli decyzję, by nie informować córki o rokowaniach. Dostała wytyczne dotyczące codziennej praktyki: inhalacje, drenaże i pastylki, które należało łykać. Została również poinformowana, że ma o swojej chorobie nie mówić innym - „że ja jestem chora, że tego mam nie wywlekać nigdzie” (148). Do tego dochodziła nadopiekuńczość rodziców oraz wyjazdy raz w roku do specjalistycznego ośrodka chorób płuc, gdzie wykonywano badania i leczono dziewczynkę dożylnie antybiotykami. Na późniejszych etapach życia wyjazdy te były częstsze, bo infekcji było więcej, a stan płuc się pogarszał.

Poza utrzymywaniem tajemnicy i zwolnieniem z zajęć wychowania fizycznego „wszystko wyglądało w miarę normalnie” (207). Istniały jednak

11 M. Gliniecka, L. Maksymowicz, A. Zalewska-Meler Tajemniczy świat muko. O problemach codziennego życia z mukowiscydozq, Teatr STOP \& Autorzy, Słupsk 2007, s. 9.

12 Por. E. Goffman Piętno. Rozważania o zranionej tożsamości, przeł. J. Tokarska-Bakir, A. Dzierżyńska, Gdańskie Wydawnictwo Psychologiczne, Gdańsk 2005. 
okoliczności, które w pewien sposób wyróżniały moją rozmówczynię i sprawiały, że czuła się inna. Pierwszą z nich była właśnie kwestia fizyczna, która doprowadziła do zwolnienia z WF-u: „bo zawsze byłam tą, co była ostatnia i co drużyna przez nią przegrywała, więc też mi się obrywało" (199-200). Drugą był kaszel: „zawsze kasłałam [...] to jest dla kogoś szok, że ja ciągle kaszlę [...] ludzie się ode mnie odsuwają [...], bo myślą, że się ode mnie zarażą" (209-214). Czasami inni uczniowie śmiali się, kiedy dziewczyna dostawała ataku kaszlu i musiała wyjść z klasy. Uważali, że robi to specjalnie, żeby opuścić lekcję. Każdą negatywną reakcję rówieśniczek i rówieśników moja rozmówczyni starała się racjonalizować. Jej najczęstszym komentarzem dotyczącym zachowań ludzi było stwierdzenie, że się przyzwyczaiła. Zdradzało ono swoiste poczucie bezsilności i braku akceptacji, które rozmówczyni w miarę możliwości odwracała, sprawiając, że akceptacja znajdowała się w jej gestii: inni nie robią niczego złego, reagują „normalnie”.

Z wiekiem pojawiły się nowe sytuacje - nieobecności, niemożność udziału w porannych zajęciach, wreszcie indywidualny tok nauczania. Tę odmienność rekompensowała jej postawa rodziców, którzy oczekiwali dobrych wyników w nauce i planowania dalszej edukacji pod kątem ciekawej pracy. Nadal jednak nie wspominano o chorobie - ,jak ktoś do mnie przychodził, to zawsze inhalator był chowany" (208-209). Moja rozmówczyni przyznała, że przed przeszczepem ukrywała swoją chorobę i dopiero kilka lat po operacji odważyła się o niej opowiedzieć. Do tej pory jednak uważa, że jest to jej sprawa i tylko ona może decydować o tym, z kim chce się tą informacją podzielić. Doszła do wniosku, że:

W ogóle ja miałam bardzo duży problem i myślę, że do tej pory mam, żeby się przyznać sama przed sobą, że jestem chora, że coś jest nie tak. I z jednej strony to jest problem, a z drugiej strony myślę, że to mi też jakoś cały czas życie ratuje... że, że... że się nigdy z tym nie mogę pogodzić (640-643).

Pod koniec podstawówki miała już świadomość, co jej dolega i jakie są rokowania. Utrzymywała to w tajemnicy przed rodzicami. Dowiedziała się o swoim stanie podczas jednego z pobytów w specjalistycznym ośrodku leczenia chorób płuc, gdzie przebywała z innymi dziećmi. „To było na porządku dziennym, że się na przykład przeglądało sobie wzajemnie pastylki... no i to było diagnozowanie na podstawie pastylek - a ty bierzesz to, [...] na to jesteś chora, no to umrzesz" (225-227). Poza tym umierali inni 
mali pacjenci i pacjentki ośrodka, co tylko utwierdzało moją rozmówczynię w przekonaniu, że jej życie niechybnie wkrótce się skończy. Dlatego zapytana po maturze o plany, wykrzyczała rodzicom, że nie ma zamiaru ich robić: „ja już wtedy skończyłam osiemnaście lat i sobie zdawałam sprawę z tego, że już nie powinnam żyć [...] szczególnie że czułam się coraz gorzej" (341-344). W 2004 roku lekarz zasugerował, by zastanowiła się nad przeszczepem płuc. Warto w tym miejscu zaznaczyć, że w tym czasie w Polsce nie wykonywano tego typu operacji u chorych z mukowiscydozą - pierwszą przeprowadzono w 2011 roku w Zabrzu ${ }^{13}$. Sugestia dotyczyła więc ośrodków zagranicznych, co wiązało się z większymi kosztami: ,jeden przeszczep - sto dwadzieścia tysięcy euro" (549-550).

Malejąca wydolność płuc i śmierć kolejnych znajomych ze specjalistycznego ośrodka leczenia chorób płuc sprzyjały pogłębianiu depresji. Ośrodek nazywano też „umieralnią”, ponieważ panujące tam warunki nie były sterylne i sprzyjały wzajemnemu zarażaniu się dzieci i młodzieży, co w efekcie prowadziło do zgonów. Stan ośrodka poprawił się w kolejnych latach dzięki inwestycjom unijnym, jednak w tamtym czasie instytucja cieszyła się złą sławą. W domu tymczasem za sprawą jednej z fundacji pojawił się koncentrator, a do leczenia włączono tlen. „Taka opinia krążyła tam, że jak się raz zacznie używać tego, to człowiek się robi uzależniony [...]. I nie jest w stanie bez tego funkcjonować" (424-427). Rozmówczyni wyznała, że pojawiły się u niej myśli samobójcze:

zawsze tak wcześniej, pamiętam, mówiłam, że jak ja się... siebie doprowadzę, jak... dojdzie do takiego stanu, że będę musiała używać tlenu, to chyba się po prostu zabiję. I tak naprawdę myślałam... Yyy... i zresztą kilku moich znajomych popełniło samobójstwo, właśnie będąc już w takim stanie, kiedy jeszcze mieli na to siłę, żeby... żeby to zrobić. A zdawali sobie sprawę, bo tak jak ja obserwowali swoich przyjaciół, którzy umierają... [głęboki wdech].Zdawali sobie sprawę, jak to wygląda (429-434).

W roku 2005 moja rozmóczyni przestała wychodzić z domu, ponieważ każda aktywność sprawiała jej trudność. Wspomina:

13 Zabrze: pierwszy przeszczep płuc u chorego z mukowiscydozq, "PAP/Rynek Zdrowia” (12.04.2011), https://www.rynekzdrowia.pl/Uslugi-medyczne/Zabrze-pierwszy-przeszczep-pluc-uchorego-z-mukowiscydoza,108114,8.html (05.06.2020). 
I w ogóle pierwszy raz w życiu wtedy... byłam w stanie na przykład zdać sobie sprawę z tego, że... że chodnik jest nierówny, tak? Że to jest pod górę. Coś, co myślę, nikomu zdrowemu by w ogóle w życiu nie przyszło do głowy, [...] podejrzewam, że to było jakieś wahanie, nie wiem, dwudziestu centymetrów, a ja to czułam, jak szłam... [4sek], że jest pod górę i ja się męczę (471-475).

Jej perspektywa z osoby „zdiagnozowanej, ale w normie” zmieniła się dość nagle na „ciężko chora”. Poczucie bezsilności i braku alternatyw coraz gorzej wpływało na jej psychikę, sprawiało, że czuła się podenerwowana i coraz mniej zdolna do jakiejkolwiek aktywności. W grudniu 2005 roku trafiła do ośrodka (umieralni) do izolatki. Dzień wcześniej w tej izolatce zmarła znajoma rozmówczyni zakwalifikowana do przeszczepu. Ponieważ nikt inny nie zgłosił się na miejsce zmarłej, moja rozmówczyni powiedziała lekarzowi, że chce mieć przeszczep.

Ja miałam wtedy pewną filozofię i, i... do dzisiaj mi to zostało... że tak naprawdę jeśli tego nie zrobię, to umrę na pewno. A jeśli zrobię, to może. Więc to była jakby prosta dla mnie kalkulacja. Myślę, że w pewnym sensie mi pomogło to, że ja widziałam, jak moi przyjaciele umierają [...] to się ciągnęło tygodniami, miesiącami, to była agonia po prostu... i nie chciałam przez to przechodzić. Absolutnie... Bałam się. [ciszej z uśmiechem] W chuj się bałam (557-563).

Moja rozmówczyni była inna nie tylko na tle swoich zdrowych rówieśników. Różniła się również od dzieci chorych na mukowiscydozę. W przeciwieństwie do nich była wysoka i dobrze zbudowana, podczas gdy typowe dziecko z mukowiscydozą jest chude, drobne i trudno określić jego wiek. Ta kwestia wielokrotnie pojawiała się podczas diagnozowania, badań, a nawet kwalifikacji. Miała też wpływ na długość oczekiwania na odpowiednie płuca. Ponieważ była jedną z pierwszych osób w Polsce po ich przeszczepie, często czuła się jak egzotyczne zwierzę w ogrodzie zoologicznym. To skupianie na sobie uwagi pracowników szpitali, które wcześniej odwiedzała jako chore na mukowiscydozę dziecko z wyrokiem śmierci, nie było komfortowe.

Drugi z wywiadów prezentuje odmienną taktykę. Zamiast ukrywać przed światem swoją chorobę, mój rozmówca postanowił wszystkim - także sobie - udowodnić, że może robić to samo co pozostałe dzieci, może być równie aktywny i nikt nie ma prawa mówić mu, że jest chory (369-373). 
Zawsze próbowałem odepchnąć od siebie chorobę. To znaczy... Za wszelką cenę udowodnić wszystkim, że choroba nie ma na mnie żadnego wpływu. Do tego stopnia, że na studiach popalałem papierosy, co dla wielu osób $[\ldots]$ chorujących na płuca - no, jest... totalnym... bez... mózgowiem, no, ale... To też miało na celu pokazać, że mi nic nie jest, tak (194-199)?

Swoje dzieciństwo określił jako szczęśliwe, z łagodnym przebiegiem choroby (168-169). Chociaż dość szybko dowiedział się, że jest ona śmiertelna, wypierał tę wiedzę, uprawiając sport i chodząc po górach. Czasami używał siły, by dowieść swoich racji.

I miałem takie sytuacje w podstawówce, że... no, gdzieś tam się pokłóciłem z chłopakami, jak to się dzieci pokłócą... i... któryś powiedział - ty i tak przegrasz, bo ty dwudziestego roku życia nie do... nieee... nie dożyjesz... Tak że... takie sytuacje miałem, ale... spuściłem wpierdol i [ze śmiechem] temat się zakończył..., że tak powiem (179-184).

Przełomowe momenty w życiu mojego rozmówcy wiązały się ze śmiercią osób chorych na mukowiscydozę i ważnymi wydarzeniami. Splatały się w czasie z pogorszeniem stanu zdrowia, co być może miało związek ze stresem i jego wpływem na system immunologiczny. Śmierć brata, której rozmówca nie widział, ale której był świadomy jako dwudziestoparoletni chłopak, sprawiła, że wreszcie zdał sobie sprawę z powagi sytuacji. Nie zmieniło to jednak diametralnie jego postępowania. Z ironią wspomina: „jak szedłem na imprezę i się napiłem, [konspiracyjnie] to miałem większe wyrzuty sumienia, [z uśmiechem] niż wcześniej" (221-223). Pomimo krótkotrwałych hospitalizacji kontynuował studia. Leczył się antybiotykami dożylnymi poza szpitalem. Wspomina: „kroplówka wisiała na lampie w domu i spokojnie mogłem się na przykład uczyć do sesji" (384-385). Później podjął pracę, ożenił się i doczekał dwójki dzieci. Właśnie narodziny dzieci były kolejnym wydarzeniem związanym ze spadkiem wydolności płuc i pogorszeniem się stanu zdrowia. Jednakże nawet spirometria na poziomie $20 \%$ nie przeszkodziła mojemu rozmówcy w kolejnych latach pokazywać dzieciom świata - podróżował z nimi do momentu zakwalifikowania do przeszczepu. Jego filozofia opierała się nie tyle na uciekaniu od śmierci, ile na robieniu planów na życie. Mój rozmówca jako zapalony narciarz wymyślał trasy narciarskie, którymi jeszcze nie jechał. Te plany były dla niego przez lata motywacją do wyzdrowienia. 
Mam coś takiego, że... zawsze jak... się źle dzieje... jak jestem w szpitalu... jak wiem, że sytuacja jest poważna... szukam sobie tras narciarskich, których jeszcze nie przejechałem [...]. I to mi daje taką siłę, że, kurczę, muszę się pozbierać, żeby móc tam jeszcze jechać. To jest takie właśnie może... może śmieszne, może dziwne, że największe plany robię zawsze, kiedy najgorzej się czuję (304-310).

Mój rozmówca zwraca uwagę na jeszcze jeden aspekt swojego życia - kiedy przychodził leczyć inne choroby, dla lekarzy w swoim mieście był często pierwszym przypadkiem osoby po przeszczepie płuc. Część z jego schorzeń wynikała z mukowiscydozy, inne z powikłań związanych z zażywanymi lekami. Diagnozowanie przypominało rosyjską ruletkę i nie zawsze kończyło się wartościową konkluzją.

W przypadku obojga moich rozmówców wyraźnie widać próbę dostosowania się do świata. Pierwsza osoba przyjmuje taktykę akceptowania i tłumaczenia reakcji otoczenia na jej chorobę, o której nie mówi, druga trzy razy bardziej stara się, by udowodnić, że jest zdrowa. Pomimo braku informacji ze strony rodziny i lekarzy młodzi ludzie poznają prawdę dotyczącą rokowań. Stygmat choroby jest wypierany, niestety świadomości śmierci wyprzeć się nie udaje.

\section{Przeszczep: kwalifikacja i ciąg dalszy}

Zdiagnozowanie mukowiscydozy nie jest jednoznaczne ze znalezieniem się na liście biorców. Oznacza tylko, że póki możliwe jest oddychanie o własnych siłach, nikt nie sugeruje przeszczepu. Kwalifikacje przebiegają w różny sposób. Inaczej opisywane są te, które odbywają się w ramach Eurotransplantu ${ }^{14}$ poza granicami Polski, inaczej te w ośrodkach zajmujących się przeszczepami w Polsce, w ramach Poltransplantu15. Lekarze w ośrodkach bardziej doświadczonych podejmują ryzyko w sytuacjach, kiedy lekarze w Polsce nie chcą sobie na to pozwolić, obawiając się śmierci pacjenta na stole lub nikłych szans na przeżycie po przeszczepie (zmarnowanie organów). Tak właśnie było w przypadku mojego rozmówcy. Dlatego podobnie jak rozmówczyni przeszedł zabieg poza Polską, w jednym z ośrodków austriackich.

\footnotetext{
14 Zob. https://www.eurotransplant.org/organs/lung/(05.06.2020).

15 Zob. http://www.poltransplant.org.pl/klo.html (05.06.2020).
} 
Droga do przeszczepu dla mojej rozmówczyni była długa i wyboista. Po szybkiej kwalifikacji w grudniu 2005 roku nastąpił okres oczekiwania - przekleństwo każdej osoby na liście biorców. W tym przypadku jednak sytuacja stawała się coraz bardziej dramatyczna. Moja rozmówczyni już nie chodziła, poruszała się na wózku. Znajdowała się stale pod tlenem. Nie można jej było zrobić spirometrii, ponieważ była za słaba. Ostatnia spirometria robiona jeszcze w Polsce wykazała pojemność płuc na poziomie $18 \%$, a do przeszczepu kwalifikuje się osoby z pojemnością od 30\% w dół. Okazało się, że trzeba wykonać jeszcze wiele badań i sprawić, by rozmówczyni przytyła. Czekanie przeciągało się, a stan pacjentki stale się pogarszał. Ponownie wylądowała w specjalistycznym ośrodku (umieralni) i trafiła do izolatki. Wysłano do niej psychologa, a następnie kolejnego i następnego - wszyscy starali się ją przekonać, żeby pogodziła się z faktem, że do przeszczepu nie dotrwa, że umrze. To wzmagało tylko jej frustrację i niechęć do psychologów. Moja rozmówczyni leżała już pod bipapem, który stymuluje oddychanie, kiedy pacjenci nie mogą oddychać o własnych siłach. We wrześniu 2006 roku lekarz prowadzący w Polsce doszedł do wniosku, że pacjentka może rzeczywiście nie doczekać operacji. Ponieważ stan był na tyle poważny, że nie można jej było przetransportować helikopterem, ośrodek w Austrii zdecydował się przyjąć ją do siebie na OIOM, żeby czekała na miejscu. Oznaczało to, że podróż do Austrii musiała się odbyć jak najszybciej.

Pamiętam,jak przyszedł do mnie mój lekarz i powiedział, że jadę [...].Na początku myślałam, że są dla mnie płuca [...]. A on potem powiedział, że nie, że jedziesz tam, żeby tam czekać. I powiem ci, że [...] poczułam że on mnie po prostu zdradza, że on chce się wyzbyć mnie, żebym ja umarła gdzie indziej. Takie miałam odczucie. Pamiętam, że absolutnie nie chciałam jechać, bo to było wtedy jedyne miejsce, gdzie ja się czułam w miarę bezpiecznie, z tą osobą, wiedząc, ile razy on mi wcześniej już uratował tak naprawdę życie, tymi lekami i tak dalej... Pamiętam, że nie chciałam bardzo jechać (721-728).

Podróż do Austrii chora odbyła w karetce pod tlenem z zapisem w karcie „otwarty proces umierania” (908). Niestety, w wyniku błędnych obliczeń doszło do zatrucia dwutlenkiem węgla. Chora miała halucynacje. Trzeba ją było podłączyć do aparatury, która gwarantowała, że przytyje. Jednocześnie około ósmego października zaczęło się konanie. Chorą zaintubowano, bo zatrucie dwutlenkiem węgla dawało o sobie znać i pod wpływem adrenaliny 
zaczęła rzucać się i wyrywać sobie wenflon. Dwunastego października lekarz poinformował rodzinę, że udało się znaleźć odpowiednie płuca. Z rozmów pielęgniarek i lekarzy moja rozmówczyni dowiedziała się później, że były to płuca mężczyzny (rozmówczyni jest wysoka), Węgra, który popełnił samobójstwo. Procedury nie przewidują informowania biorców o tym, od kogo pochodzą organy, w związku z czym te informacje są jedynymi, jakie kiedykolwiek uzyskała.

Po wybudzeniu dzień po przeszczepie moja rozmówczyni miała wrażenie, że coś poszło nie tak, że przeszczep się nie udał. Jak sama stwierdza, o przeszczepach nie wiedziała nic. Była drugą osobą w Polsce, która przeszła transplantację płuc. Jej koleżanka swoje doświadczenia opisywała w jasnych barwach, co, jak później się okazało, miało na celu zachęcić innych do przeszczepów. Moja rozmówczyni ocenia ten pomysł negatywnie, ponieważ po samej operacji czuła się dużo gorzej. „Ja autentycznie czułam się tak źle jak... jak nigdy w swoim życiu się nie czułam. I był taki moment, że żałowałam w ogóle, że to zrobiłam, i że lepiej było umrzeć, autentycznie" (804-806). Największy wpływ miał na to fakt, że rozmówczyni nadal nie chodziła, załatwiała się pod siebie i była zdana na pomoc obcych ludzi, posługujących się między sobą nieznanym jej językiem niemieckim: „myślę, że to jest taka granica wstydu, której już... jakby dalej nie ma nic" (808). I choć pacjentów po przeszczepie wypuszczano zwykle po dziesięciu dniach ze szpitala, moja rozmówczyni sądziła, że prędzej umrze, niż gdziekolwiek wyjdzie (821). Przez miesiąc była na OIOM-ie, gdzie ustawiano jej leki. Znowu pojawiły się halucynacje, agresja wobec personelu medycznego i autoagresja z zamiarem popełnienia samobójstwa. Została więc unieruchomiona pasami. Do tego pomimo morfiny odczuwała ból. Kolejny miesiąc trwała nauka oddychania i chodzenia. Po dwóch miesiącach w Austrii moja rozmówczyni wróciła do Polski i na nowo zaczęła się zastanawiać nad życiem i przyszłością. Wybrała także studia, psychologię - głównie po to, by udowodnić psychologom, których spotkała w ośrodku (umieralni), że z chorymi i umierającymi można rozmawiać lepiej.

Zupełnie inaczej potoczyły się losy mojego rozmówcy. Po szybkiej kwalifikacji, udało się znaleźć sponsorów i już pod koniec maja pieniądze były w $\mathrm{Au-}$ strii. W czerwcu odbyła się operacja. Nie było czekania w nieskończoność, nie było konania ani zatrucia: „ja ten przeszczep przeszedłem jak [uśmiech] wycięcie wyrostka. Ja byłem trzy dni na intensywnej terapii. Po trzech dniach zostałem wypisany ze szpitala" (266-268). Mój rozmówca wspomina ten czas jako przyjemny, ponownie mógł oddychać pełną piersią. Wyniki miał 
świetne, ale chociaż ściśle przestrzegał zaleceń austriackiego ośrodka, po dwóch latach nastąpił odrzut. „I to był taki bardzo ciężki moment, yy wcześniej przez dwa lata... za każdym razem, jak jechałem na kontrolę, wyniki były coraz lepsze. Nawet nie, że były stabilne, były coraz lepsze. Dochodziłem do formy takiej... sportowca - zacząłem ćwiczyć crossfit" (277-279). Lekarz przekazał mu złą wiadomość - konieczny był drugi przeszczep. Polska w tym czasie wyszła z Eurotransplantu, co oznaczało, że do dyspozycji pozostawały jedynie polskie ośrodki. Mój rozmówca stwierdził, że w kraju cała procedura przebiegała zupełnie inaczej i że udało mu się trafić na dobrych fachowców, którzy w innych okolicznościach, z mniejszą liczbą ograniczeń, mogliby zrobić znacznie więcej. Najtrudniejsza okazała się dla niego walka z samym sobą i przekonywanie, że będzie dobrze. Swoje przygotowanie do przeszczepu mój rozmówca uznał za bardzo dobre. Gorzej zniósł informację po wybudzeniu, że przeszczepiono tylko jedno płuco, a jego operacja składała się właściwie z trzech oddzielnych interwencji. Zdał sobie sprawę, że, czuje niedosyt” (339). „Teraz [...] najwięcej [...] wysiłku tak naprawdę zajmuje... yyy... wypracowanie tego, żeby się cieszyć... z małych rzeczy... i nie katować się tym, że... żeee... no, półmaratonu już nie przebiegnę na przykład [...] I przestałem robić jakiekolwiek plany" (343-348). Rzeczywistość stała się mniej przewidywalna. Wszystko zostało podporządkowane ewentualnej konieczności pojawienia się w szpitalu. Mój rozmówca nie interesował się, od kogo ma płuca - za każdym razem był za nie wdzięczny, ale zgodnie z wymogami prawa nie potrzebował wiedzieć, kto jest dawcą.

W badaniach jakości życia chorych na mukowiscydozę po przeszczepie płuc wskazuje się na trudność w zaakceptowaniu rzeczywistości po transplantacji ${ }^{16}$. Wynika ona głównie z oczekiwań związanych z wyleczeniem. Chorzy na mukowiscydozę nie pozbywają się choroby, lecz jedynie zwiększają wydolność płuc. Przy czym różnica ta nie zawsze jest zauważalna zaraz po operacji, co potęguje frustrację.

\section{Nierówne perspektywy na dalsze życie}

Życie po przeszczepie pełne jest zakazów i nakazów. Mężczyźni z mukowiscydozą po przeszczepie płuc poza lekami i listą rzeczy, których powinni unikać (lista jest uwarunkowana doświadczeniami ośrodka dokonującego

16 Zob. G. Dębska, G. Cepuch, L Pawlik Postrzeganie życia, jego celu i sensu przez chorych na mukowiscydozę po przeszczepie płuc, „Folia Medica Cracowiensia” 2011 t. LI/1-4, S. 20. 
przeszczepu), nie odczują większych ograniczeń. Nie mogą jeść pewnych produktów, nie mogą kąpać się w zamkniętych zbiornikach wodnych, nie powinni mieć zwierząt (ale jeśli przed przeszczepem w domu było zwierzę, to przyjmuje się, że nie będzie ono miało negatywnego wpływu na ich zdrowie). Jeżeli chcą założyć rodzinę - mogą to zrobić. Muszą pamiętać o badaniach genetycznych, żeby zapewnić bezpieczeństwo potomstwu, tak by było ewentualnie „zdrowymi nosicielami” (398). Mój rozmówca wykonał takie badania i razem z żoną podjęli decyzję, że chcą mieć potomstwo. Jednocześnie liczy na to - co kilkakrotnie powtarzał - że medycyna zdoła rozwiązać problem muskowiscydozy do czasu, kiedy jego dzieci będą zakładały swoje rodziny, dzięki czemu nie będą musiały martwić się o to, że przekażą dalej wadliwy gen.

Sytuacja kobiet z mukowiscydozą po przeszczepie płuc jest trudniejsza. Ich ewentualne marzenia o założeniu rodziny są praktycznie niemożliwe do realizacji. Własnych dzieci mieć nie mogą. Osoby, które uważały ten zakaz za niedorzeczny, szybko przekonały się o tym, że nie warto odstawiać leków, bo kończy się to powolnym konaniem i odrzutem przeszczepu. Adopcja też nie wchodzi w grę, bo prognozy dotyczące przeżywalności i zdolności do sprawowania opieki nad dziećmi nie są zachęcające. Kobiety rozpatrujące związek z mężczyzną, który już ma dzieci, stają przed dylematem, czy w przypadku pogorszenia się stanu ich zdrowia mężczyzna nie wybierze dzieci i nie zostawi chorej kobiety wymagającej opieki. Sytuacja jest więc wyjątkowo skomplikowana i nierówna. Presja posiadania dziecka odbija się na psychice kobiet i postrzeganiu sensu własnej egzystencji, wartości i celowości istnienia. Brak możliwości przekazania doświadczeń sprzyja powracającym stanom depresyjnym. Moja rozmówczyni wspomina również sytuacje, kiedy było jej przykro, bo rodzina mężczyzny, z którym się spotykała, lub jego znajomi odnosili się do niej niechętnie. Hasło „stać cię na więcej” (1076) przeczytane w wiadomości tekstowej od mamy człowieka, który był jej bliski, bardzo ją zabolało i utkwiło mocno w pamięci. Do tej pory powtarza je przy okazji każdego kolejnego związku.

Dodatkowym aspektem jest kwestia fizyczności. Osoba po przeszczepie ma blizny. Nie zawsze są to ślady, które można ukryć i które nie pociągną za sobą rozmowy o przeszczepie i chorobie. Są one widoczną oznaką czającej się choroby, która została tylko „zaleczona”. „Wszystkim swoim chłopakom się przyznawałam, no bo wystarczyło, że ściągnęłam bluzkę, i było widać, że jestem pokrojona po prostu" (116o-1161). Przeszczep płuc u kobiet z mukowiscydozą częściej więc pociąga za sobą możliwość pojawienia się depresji 
i poczucia niedopasowania, kwestionowania własnej atrakcyjności. Powraca więc problem inności i nieustannego negocjowania swojej pozycji w świecie.

Warto w tym miejscu powrócić do kwestii mówienia o chorobie. Wątek ten podejmowany jest w biuletynie „Mukowiscydoza”: „trzeba być świadomym tego, jaki obraz choroby przekazujemy dziecku. A co za tym idzie - wpływamy na jego obraz siebie jako osoby chorej («Czy jestem inny?», «Czy moja choroba jest tematem tabu?»). Namawiam do tego, by o chorobie rozmawiać jak najbardziej naturalnie"17. Trudno stwierdzić, czy odmienne podejście rodziców moich rozmówców do kwestii informowania dzieci o specyfice choroby przyczyniłoby się do zmiany ich sposobu postrzegania siebie. Mam jednak wrażenie, że życie z nieuleczalną chorobą może być satysfakcjonujące.

\section{Zakończenie}

W niniejszym artykule nie poruszyłam szerzej kwestii związanych ze społecznym postrzeganiem przeszczepów czy etycznymi przesłankami do ich przeprowadzania. Nie zdecydowałam się na to, ponieważ podjęcie tego zagadnienia nie daje pewności dojścia do rozstrzygających wniosków. Transplantologia od lat jest postrzegana z jednej strony jako dziedzina medycyny, która ratuje życie, z drugiej - porównuje się ją do „współczesnej odmiany kanibalizmu"18. W przeprowadzonych wywiadach również pojawił się ten wątek - jeden z przyjaciół rozmówczyni (chorujący na mukowiscydozę) zapierał się, że nie będzie miał w sobie „trupa”. Po transplantacji przeprosił za swoje słowa. Podejście do przeszczepów nie jest więc czymś stałym i niezmiennym - zależy od wielu czynników, oswojenia z tematem, bliskości, zrozumienia, a także od poglądów religijnych. Uznałam więc, że bardziej potrzebne i przydatne będzie spojrzenie na losy osób po przeszczepach płuc, na to, w jaki sposób postrzegają one swoje życie i decyzję związaną z transplantacją. Szczególnie przypadki osób chorujących na mukowiscydozę pozwalają dostrzec problem nieustającego balansowania między życiem a śmiercią. Ważne, by o tym rozmawiać publicznie. Choroba nieuleczalna nie tylko zmienia perspektywę, ale nie pozwala na stabilizację - odczuł to dobitnie mój rozmówca po swoim drugim przeszczepie. Nagle nie można już niczego zaplanować, żyje się

17 U. Borowska-Kowalczyk Czy warto informować o chorobie dziecka i prosić o wsparcie? „Mukowiscydoza" $2016 \mathrm{nr}$ 47, s. 22.

18 A. Zalewska Nadzwyczajna recepcja transplantacji. Jak dyskusja o etyce przeszczepów może zmienić nasz porządek kulturowy, „Konteksty Kultury” 2016 nr 13 Z. 1, s. 81-82. 
z dnia na dzień. Widmo kolejnego przeszczepu przeraża, a niepowodzenia z nim związane sprawiają, że chore i chorzy kwestionują sensowność takiej operacji.Tymczasem na świecie są już osoby z mukowiscydozą, które przeżyły trzeci przeszczep ${ }^{19}$.

Pomimo wielu problemów, które pojawiają się po przeszczepie i których osoby chorujące na mukowiscydozę nie są świadome przed wyrażeniem chęci znalezienia się na liście biorców, moi rozmówcy czują wdzięczność. Stają do codziennej walki. Nie poddają się. Nawet jeśli na początku mieli wątpliwości, to ta niezwykła szansa na dłuższe życie skłania ich do wielokrotnych podziękowań. Kierują je nie tylko do dawczyń i dawców oraz ich rodzin, ale również do lekarek, lekarzy i personelu medycznego. Starają się doceniać każdy nowy dzień, łapczywie wdychają powietrze, póki mogą robić to o własnych siłach.

Kształtowanie się tożsamości osób chorujących na mukowiscydozę, które mają za sobą doświadczenie przeszczepu płuc, jest złożonym procesem negocjowania swojego statusu. Obejmuje on diagnozę, odczłowieczenie i utratę podmiotowości oraz sprawczości, poczucie ułomności cielesnej, ponowne uczenie się oddychania, chodzenia, jedzenia, szukanie miejsca dla siebie po przeszczepie, ból fizyczny i psychiczny, depresję, oczekiwanie najgorszego lub liczenie na cud, wreszcie odliczanie dni, pogłębiającą się niepełnosprawność, kolejny przeszczep lub śmierć. Osoby z mukowiscydozą mają poczucie odmienności, które nie znika, chociaż zmienia się w czasie, odsłaniając kolejne pokłady inności, którą pragną w jakiś sposób zasłonić.

19 N. Vakil, D. P. Mason et al. Third-time lung transplantation in a patient with cystic fibrosis, "The Journal of Thoracic and Cardiovascular Surgery" 2011 vol. 141 no. 1, s. e3-e5. 


\section{Abstract}

\section{Łucja Lange}

UNIVERSITY OF ŁÓDŹ

Identity and Uncertainty: Life after a Lung Transplant

Lange discusses identity formation in people who have received a donor organ, taking cystic fibrosis patients with lung transplants as an example. Two narrative interviews form the basis of this analysis. They allow Lange to trace the processes and the turning points in the lives of concrete individuals with cystic fibrosis. These people's changing identity and their chronic awareness of their own mortality makes them constantly doubt their decision and they are always learning to live with the stigma of an incurable disease. Their stories not only allow us a glimpse into living with cystic fibrosis, but they also show intertwined feelings of gratitude, anger and helplessness in the face of the disease, the bureaucracy, political shifts and more.

\section{Keywords}

cystic fibrosis, lung transplant, identity, stigma of illness 